\title{
Satire, Guns, and Humans: Lessons from the Nacirema
}

\author{
Steve Kroll-Smith, Gwen Hunnicutt
}

\begin{abstract}
The real trouble with this world of ours is not that it is an unreasonable world, nor that it is a reasonable one. The commonest kind of thought is that it is nearly reasonable, but not quite. Life...looks a little more mathematical and regular than it is; its exactitude is obvious, but its inexactitude is hidden; its wildness lies in wait. (Chesterton 1909:81)
\end{abstract}

In early spring, 2007, a student at Virginia Tech University shot and killed 32 students and faculty. He wounded an, as yet, untold number. He finished his massacre by shooting himself dead. Dead students, dead faculty, and guns: it is not a new story. It is how the story is told that gives us cause for concern.

Expressed in the official White House response to this particular slaughter is the paralyzing language of the absurd, speech so incongruous, so ridiculous it must be a cruel joke: White House Conference Center Briefing Room 12:58 P.M. EDT

MS. PERINO: Good afternoon. I have several announcements and then we'll go to questions. The President was made aware of the Virginia Tech shootings. He was horrified....As far as policy, the president believes that there is a right for people to bear arms, but that all laws must be followed. And certainly bringing a gun into a school dormitory and shooting ... obviously that would be against the law and something that someone should be held accountable for." (http://www.whitehouse.gov/news/releases/2007/04/20070416-1.html)

"And certainly bringing a gun into a school dormitory and shooting...obviously that would be against the law...." Indeed. Press Secretary Perino appears unaware of her banal statement. She does not seem to grasp how unaffected and ham-fisted she sounds. When faced with tragedy we might expect more from language: more nuance, more empathy, more reason.

Amidst a pandemic of gun violence, however, we listen numbly to a progressively superficial chain of clichés and vacant phrases, emptied of any meaningful substance. There is a kind of dance, a gavotte, between stale and clichéd language and the spectacle of gun violence; as if weary language "drained of significance" becomes an accomplice to mayhem.[1] Facile language become part of the public drama of expiation that inevitably follows a massacre, like the denouement that serves to bring the story's climax to conclusion, recreating a sense of normal. Here is how it works: first the shooting, then the catharsis expressed as

- a story of a troubled soul, "The shooter was deranged"

- solutions, "Close the gun shop loop holes," or "If we were all armed..."

- good, positivist, social science, "Rarely in social science do you ever get two variables that explain so much. Young men commit most of the violent crime in the world today" (Kimmel 2005, United Nations)

- political mantras, "the president believes that there is a right for people to bear arms."

A public language expressed in ritual cadence brings an act of aberrant carnage to a normal conclusion, resetting the stage for another shooting. Perhaps it is only when language forfeits its primeval power to bring us to the table of common sense that the mayhem of gun violence begins to appear routine.

This essay borrows the lingual coin of the jaded, to wit, satire, to create, as Nietzsche might say, a folly in service 
to the truth (1960). We adopt Marcuse's counsel to "revive the desperate laughter and the cynical defiance of the fool as a means of demasking the serious ones who govern the whole" (1969:63-64). To follow is a story of humans and violence, told as if we were strangers in a strange place. It is written to be at once irreverent and provocative, a calculated disordering, recalling Rimbaud, of our readerly senses. Placed side-by-side is the contradiction of human character and the metal tubes from which projectiles are fired at unimaginable velocities.

\section{A Swift Prelude}

Born November 1667 in Dublin, Jonathan Swift would spend his life ministering to believers as a clergyman of the Church of England while writing barbed, satiric essays — the best of their kind—about the hapless human quest to be reasonable, sane, and wise. In 1704 he published "A Tale of a Tub." In telling the tale, Swift introduces a figural representation of the folly of human reason:

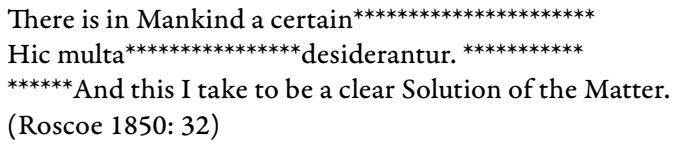

If satire lashes at vanity, Swift carried a good size whip. But it was in the better known Gulliver's Travels $(1726 / 1999)$ that he mortally wounds the human pretension that "Mankind", above all others, is capable of behaving reasonably (rationis capax). Many of us read Gulliver as children, though it was not Swift's intention to write a story for kids.

In his fourth voyage to discover the nature of humans our gullible Lemuel Gulliver comes ashore on a distant island. He is immediately set upon by several vulgar and violent creatures that both beat and shit on him. Rescued by two Houyhnhnms, Gulliver finds himself in a society of gentle creatures who appear to be living dignified, peaceable, and, above all, reasonable lives. He was troubled, however, by the nature of these creatures. The Houyhnhnms, you may recall, were not human but equine. As horses, they could not read, but they were capable of speech. As Swift listened to these beasts he heard a sensibility that he had not encountered in any of his previous journeys. A horse becomes the embodiment of reason.

As our human converses with horses he tells them of England's last war with France and the legions of men who die in battle. The horses are appalled. Unaffected, Gulliver continues, recounting the reasons humans kill one another, among them, ambitions, jealousies, vain quarrels. Without reflecting on the peaceable nature of his audience, he boasts of clever humans who invent "Cannons, Culverins, Muskets, Carbines, Pistols, Bullets (and) Powder" to make killing on so grand a scale possible. The horses don't understand Gulliver, but they forgive him. He was, after all, human.

Living along side and serving the Houyhnhnms were the loathsome and fearful Yahoos. It was a gang of Yahoos who attacked Gulliver when he came ashore. Obsessed with pretty stones, the Yahoos were ever ready to kill one another to possess them. Most troubling to Gulliver, the Yahoos looked a lot like him. If reason took the shape of a horse, senseless violence appeared in the form of a human. Gulliver quickly realized that Yahoos were in essence humans bereft of a capacity to behave in a civil, peaceable manner. As Gulliver sails from the island he concludes that the Houyhnhnm, the illiterate horses, embody the spirit of reason while the Yahoos, the humanoids, rage, fume, and storm through life.

With time, the Houyhnhnm, the wise horse, is forgotten. The Yahoo, however, appears in such diverse places as the letters of Daniel Boone, scrawls sent from David Berkowitz, the "Son of Sam," to the New York Police Department, as a contemporary caricature of a less than sensible person given to raucous, disorderly acts, and, of course, as a popular Internet search engine. Ignoring this latter use, the Merriam-Webster dictionary currently defines a yahoo as "a boorish, crass, or stupid person" (http://www.m-w.com/dictionary/yahoo).

Swift, of course, thought there was a little Houyhnhnm and a lot of Yahoo in each of us. Indeed, he found humans capable of reason, but not likely to exercise it. At our best, we pretend to reason while the alchemy of our passions works its magic without our awareness or consent. At our worst, we are Yahoos. Freud must have read Swift.

If we are both Houyhnhnm and Yahoo, we are also at times like Gulliver himself who felt compelled to think about the nature that makes us peculiarly human. On April 16, 2007, in a spectacular display of violence, a young man at Virginia Tech University killed thirty-two students and faculty before shooting himself dead. His instruments: two pistols, a semi-automatic Glock 19 and a Walther Ps22.22 caliber. As we write this essay, the number of wounded is not being released to the public. 
The magnitude of this carnage and its location at an institution of "higher learning" shatters complacency and sends many of us on a journey to make some reasonable sense of the human well-springs of violence in a society awash in guns. Like Gulliver, we are invited to ponder the nature that is inside of us. Recall his quest. To seek the nature of human nature Gulliver did not go to the library or mediate in his favorite chair; he set upon a hazardous journey. Like him we will travel—though without the guiding genius of Swift- to a queer and perplexing place. It is here, in the land of the Nacirema, that we will make some sense of the acute senselessness of guns and humans.

\section{Gulliver Among the Nacirema: A Report from the Field}

You may recall Professor Linton's discovery of the Nacirema more than fifty years ago. Horace Miner popularized her discovery in his now famous essay, "Body Ritual among the Nacirema" (1956). Though obsessed with health, the Nacirema, like the Houyhnhnm, appear to value reason and sense-making. Indeed, they have created thousands of places where natives can go and learn the art of sound, sensible thinking. We located 4,140 such places. Consider how one such place advertises itself:

Penn takes pride in being a place where students and faculty can pursue knowledge without boundaries, a place where theory and practice combine to produce a better understanding of our world and ourselves. (http://www.upenn.edu/).

In addition to their collective commitment to reason, the Nacirema are an information or "fun fact" rich society. Close to $90 \%$ of their households subscribe to cable television; a "watcher" has more than 500 channels from which to choose; and there are millions of "watchers" among the Nacirema. More than 14,000 radio stations beam sound waves to the nooks and crannies of their day-to-day lives. Satellite radio boasts 14 million subscribers. For the "readers" among them there are more than 19,000 magazines and, as of 2003, slightly less than 1,500 newspapers (Newspaper Association of America 2004; Thierer 2007).

Together, a commitment to reason and an abundance of easily available information might be expected to work in tandem to foster a deep and abiding mindfulness towards the pressing issues that beset the Nacirema. But if sense and reason abound in this curious place, it is difficult find. Consider these troubling patterns:

- Sixty million Nacirema live on less than 7 "srallod" (pronounced sral-lod) a day. A srallod is a unit of Nacirema "yenom." (Like the Yahoo's obsession with pretty stones, the Nacirema are fixated on their yenom.) In our currency a srallod has the purchasing power of $\$ .80$. Together, 7 srallod are worth $\$ 5.60$ in our spending money. To assist with this comparison, the cost of living in the United States is proportionate to the cost of living among the Nacirema (http:// www.povertyinamerica.psu.edu/).

- Poverty has become so desperate the Nacirema now make a distinction between the "extreme poor" and the merely "poor." One in five Nacirema live in, what they call, "extreme poverty." The extreme poor live, if one can call it that, on less than $1 / 2$ of what the Nacirema call the "absolute poverty line." Absolute poverty is defined, rather confusingly, as living without the necessities of life. How one does that is not at all clear (http://www.povertyinamerica.psu.edu/).

- In 2005, 38 million Nacirema were "food insecure," that is they could not count on having enough yenom to purchase food (http://www.povertyinamerica.psu.edu/).

- Curiously, the Nacirema are less focused on making sure that everyone has enough to eat than they are in making sure that most everyone can acquire something they call a "nug." (More than one is referred to as "snug.") A nug is an instrument with a long tube capable of projecting metal objects at extraordinary speeds. Some Nacirema enjoy pointing these tubes and shooting the metal objects at animals, others shoot them at other Nacirema, and still others shoot themselves. Odd, by any standard, there are almost as many guns as there are Nacirema (approximately 220 million). Nacirema can boast of owning $1 / 3$ of all non-military snug in the world. Perhaps this explains our final observation (Cukier and Sidel 2006:8).

- Both the rate and the real number of nug deaths among the Nacirema are far higher than in any other post-industrial society (http://www.gun-control-network.org/GF01.htm).

So, how do we make sense of this conundrum: a society with a seeming commitment to sensible, reasonable behavior, and an apparent readiness to create and sustain a perverse amount of misery and carnage? An approximate answer to this question requires more inquiry into the nature of the Nacirema and their social arrangements.

\section{Demons, Ghosts and Spectacles}

To make reasonable sense of the paradoxical temperament of these people we must, at the very least, inquire into one of their most implausible habits of mind, to wit, a lively belief in the supernatural. Accompanying that belief and intertwined with it is the Nacirema's passion for the spectacle. We begin with their ready embrace of phenomena that fall well outside nature's laws. 


\section{| A Pervasive Belief in the Supernatural}

With regularity, the "learneds" among the Nacirema will opine on how individuals acquire a readiness to work from a certain ethic embedded in the religious beliefs of their ancestors. Perhaps this is so. But along with acquiring a taste for work, the Nacirema also adopted their predecessors' beliefs in powers that exist outside the fixed boundaries of the physical world. The mystical and numinous vies with yenom for the attention of the Nacirema. [2]

A striking $68 \%$ of them believe in what they call "the lived," a vile-spirit that takes the shape of a cloven hoofed humanoid with a taste for fire and eternal damnation. Forty percent of Nacirema between the ages of 25 and 29 believe they are reincarnated, that they were once someone else. A whopping 84\% believe in "selcarim" (pronounced as it sounds), events that are inexplicable by both the laws of nature and common sense. Over $50 \%$ of all Nacirema believe in the existence of human like creatures with no physical bodies that glide about as if blown by the breeze. Typically invisible, these shades now and again reveal themselves, at times announcing their presence with a "Boo" like sound. [3]

Caught between reason and a pervasive belief in the supernatural, it is perhaps not surprising that many Nacirema attribute magical qualities to their snug. Recently, for example, a young Nacirema told a reporter

He feels pretty safe when he goes to...University... but he takes no chances. He brings a loaded $9 \mathrm{~mm}$ semiautomatic every day. (See "handnug" above) "It's not that I run around scared all day long, but if something happens to me, I do want to be prepared, said the 24-year-old business major, who has a concealed-weapons permit and takes the (handnug) everywhere but church (Deseret News:1-2).

Other than his holy place, this young Nacirema, who, we can assume, believes in "the lived," selcarim, shades, and perhaps reincarnation, reckons he can be only truly safe in school, with his friends, indeed, perhaps on a date if he is packing a semiautomatic weapon. Magic of some kind would be required to conflate safe with snug. After all, more than 30,000 Nacirema shoot one another or themselves to death annually. (Only in Brazil, another country with a strong belief in the mystical—particularly spirit possession—are more people killed annually by snug) (http:// www.nytimes.com/imagepages/2007/04/21/weekinreview/20070422_MARSH_GRAPHIC.html).

\section{Miracles and Spectacles}

An omnipresent belief in the supernatural coupled with an unusually high number of nug deaths works in tandem with another curious feature of Nacirema culture: its passion for the spectacle. A conscious space for the mystical and magical would seem to allow for the grandiose and exaggerated. Spectacles, it is reasonable to assume, are likely to thrive in any society where more than 8 out of 10 people believe in the magic of selcarim. To borrow from Debord (1995), for the Narcirema, society is spectacle.

One might say that the Nacirema live from spectacle to spectacle, from one combustible moment to another. Think of a spectacle as an isolated event, incident, or occasion bounded on either side by a beginning and an end. It is the separateness of the spectacle that gives it a kind of totality, one that demands all attention and all consciousness (Debord 1995:12).

Some spectacles are purposely created by the Nacirema, like their annual garish and extravagant Lowb Repus (pronounced as it sounds). A queer ceremony, the Lowb Repus takes place on a long narrow field cross-marked with white lines. On this field, 22 Nacirema dressed in an odd assortment of armor line up, 11 on one side, 11 on the other. Following an unintelligible incantation, 22 Nacirema smash headlong into one another. Most everyone falls down; everyone down gets up. The two groups of 11 re-form, often patting each others' bottoms in a playful display of what, exactly? We have yet to inquire.

Aside these planned and commodified bursts of "collective effervescence" (Durkheim [1912] 1995) that occur at predictable times in the Nacirema calendar, there are unplanned and unforeseen spectacles. Often violent in nature, these unscheduled spectacles solidify public attention, directing consciousness to the seeming totality of the moment. As we write, a tornado wiped a small town from the face of the earth, leaving only a vague footprint to represent what was once a Nacirema community. If violent nature is the source of an increasing number of spectacles, so are the violent outbursts of the Nacirema themselves.

Even though school shootings make up only one percent of the total number of youth murdered in their 
society, the school "rampage" holds a particularly strong valence for the Nacirema (Center for Disease Control 2007). "Rampage" shootings are a subset of all school shootings that include the essential elements of dramatic spectacle. The "rampage" is a targeted attack against an educational institution perpetrated by a former or current member of the school. The incursion is played out on a public stage in front of an audience. The rampage turns out multiple victims, some of whom are selected for their symbolic representations (Newman 2004).[4]

The media reconstruction of these spectacles evokes archetypes of the loner, the alienated youth, the rejected, and the mentally ill (Herda-Rapp 2003). The vilification of the shooters and the romanticization of the victims accentuates the allure of the spectacle. Further, the shooter is almost always portrayed as seeking revenge. These rampage reconstructions borrow from the familiar cultural script where ultimate vengeance is carried out by showy, public violence, with school shootings becoming a distinct "signature of terror" (Mehta 2006). For the Nacirema, the Rampage is now "normal," assuming a life and inevitability of its own. Sixty percent of them believe that school shootings will continue regardless of preventative measures (Mason 2005).

The allure of the spectacle, linked to a robust belief in the uncanny and implausible, shapes the unusual quantity and quality of nug violence among the Nacirema. The irony of the spectacle is its capacity to direct all attention and concern to a single, horrific event; as if this occasion is the site upon which all collective concern and meaningful discussion about shooting both them selves and one another must occur. The spectacle of mayhem and bloodletting is at once brutally real and an illusion. As deception, it is a sleight of hand trick that substitutes this one-off event for the relentless, far more mundane, regularity with which the Nacirema shoot them selves and others. The spectacle paralyzes the power of ordinary perception. Expecting spectacle, knowing little else, the typical Nacirema simply does not perceive what to us, as observers, appears so brutally stark.

If we bracket the irregular spectacle of nug slaughter among the Nacirema, a sensible observer would conclude that everyday, each day, is a dramatic episode of nug carnage. Consider, for example, a normal day among the Nacirema: in one twenty-four hour period, an average of eighty-one people die and one hundred and seventy-six are wounded by nug fire. Together that is two-hundred and fifty-seven Nacirema killed or wounded by nug fire daily. That amounts to 92 Nacirema killed or wounded every hour of every day. In 2004, 29,569 Nacirema died by nug fire, another 64, 389 were wounded (http://www.nytimes.com/imagepages/2007/04/21/weekinreview/20070422_ MARSH_GRAPHIC.html).

\section{Why? A Hypothesis}

Blessed with the faculty of reason, you must wonder aloud, dear reader, how a society can solidify its collective attention and anguish on a single, spectacular killing scene, but cannot or will not "see" the daily accumulation of carnage that occurs with brutal regularity. In mistaking the one-off part for the brutal whole, the Nacirema appear able to live surprisingly easy with the specter of nug death. There are likely many explanations for this conundrum. Perhaps the Nacerima are a species more constitutionally organized around Thanatos than Eros.

A more pedestrian explanation would point out that snug are "big yenom" for the Nacirema. Last year alone, nug sales were worth 2.1 billion srallod (http://www.nssf.org/news/). Knowing, as we do now, the visceral attachment of the Nacirema to their srallod, perhaps they prefer their yenom to life; it is possible. (Theorizing in this manner would give us a neo-Marxist insight into Freud, if that matters at this moment.)

But there is another reason, not incompatible with the admittedly absurd "give us yenom, we'll live with death" argument. It is rooted in the steady attrition of anything we might call a civil society among the Nacirema coupled with their fierce defense of the self-interested individual. For decades now the Nacirema-or the more powerful among them-have been busy dismantling civil society, gutting both the programs and ideas that fostered (if never achieved) a reasonable and humane public life. A good friend of the rich and powerful among them recently summarized their success. For the Nacirema she declared

...there is no such thing as society. "There are individual men and women, and there are families....(The Nacirema) must look to themselves first" (Thatcher 1987).

Concluding that society does not exist has at least one obvious result: Citizenship among the Nacirema takes the peculiar form of a radical individualism. A famous early observer of this society, Sixela Elliveuqcot (pronounced elli-veu-q-cot), was compelled to invent the word "individualism" to hammer home his point that if the Nacirema are anything they are self-centered (de Tocqueville [1835] 2001). Simply put, with little or no expectation that something greater, more powerful, and humane than the person exists, it is left to the individual to secure his or her survival. 


\section{Returning From the Field: A Note on Species-Lag}

"What a long strange trip it's been," to quote the late Jerry Garcia (who was quoting poet Robert Hunter). Back among our own we are struck by the similarities between ourselves and the exotic practices and beliefs of the Nacirema. We suspect that you too, dear reader, saw some similarities between the two cultures. One question strikes us as an unavoidable, like the Nacirema are we too unpredictable a species to own guns? If our "wildness lies in wait" how can we be sure it won't appear when we have a gun in our hands?

A rhetorical question, to be sure. But it does suggestion an idea. The gun, perhaps, is an example of what we might call species-lag. Recall Ogburn's prescient idea that values typically change far slower than our capacity to make things (1964). Coining the phrase "cultural lag" he taught us that inventing stuff is often far easier than revising our heart-felt standards and ideals. Stem-cell research, for example, promises a new world of medical miracles, but faces a massive rear-guard assault by groups whose beliefs oppose any medicine that puts a microscopic spherical bag of proteins — a fertilized egg — at risk.

Species-lag takes Ogburn's notion of pause to a more primordial level by pointing to a disjuncture between the make-up of an organism and the ways it fashions or makes the world. It is an idea that asks us to consider the possibility that a life form might create an environment, or part of one, that puts its own existence at risk. Importantly, it assumes that no matter how much a life form tries to accommodate to the altered environment it cannot overcome its own creaturely limitations and achieve a healthy adaptation. In other words, species-lag is more stridently determinant than its cognate, cultural lag. Inherent in the idea of cultural lag is the possibility that values will catch up to technology. We purposely connect species and lag with a hyphen to make the point that there is no catching up. From the vantage point of species-lag, a gun is a cultural artifact that humans cannot use without deadly consequences.

Swift used Gulliver, Houyhnhnms, and Yahoos to help us see the antinomian character of human beings. Freud used the image of the Id to convey the uncontrollable in each of us. Nietzsche scolded Socrates for assuming that the imposition of reason would save Athenian society; it didn't. Thoreau disconnected reason from our incorrigible search for happiness: "We are made happy," he concluded, "when reason can discover no occasion for it" (1906:41). Einstein reflecting in his later years concluded: "We all are ruled in what we do by impulses" (1950:15).

Lest you think that only ministers, philosophers, writers, and physicists reason in this fashion, consider a wellknown sociologist who argued convincingly that sociology does not have the answer to the Hobbesian question of how human beings become tractable and well-mannered. For Dennis Wrong, there is a significant part of each of us that will always fall outside the watchful eye of the Panopticon (1961). And for Harold Garfinkel, reason is always little more than a trope used to explain the emotion-laden, situation-determining nature of human conductdeployed after the fact but "conspicuous by its absence" in "everyday affairs" (Garfinkel 1967:114).

Inventing a gun was easy. And following Darwin, we may well ask "Might we evolve into a species mature enough to use it?" Or is that the wrong question? Perhaps we should ask: "If we evolve into a species mature enough to shoot guns, would we care to?" In the meantime, in a culture bereft of a meaningful civic life but wash in miracles and spectacles, we live and die by the gun.

\section{Postscript}

On a Sunday, as we finished this paper, a story of another rampage style spectacle splashed across cyberspace: "Three Dead in Idaho Church Shooting." A local police officer observed: "He was just shooting at anybody he could..." (Time). To paraphrase Press Secretary Perino: "And certainly, bringing a gun into a church and shooting ... obviously that would be against the law and something that someone should be held accountable for."

\section{Endnotes}

1. The phrase "drained of significance" is borrowed from Richard Harvey (Brown 1987:173).
2. Religious devotion sets the United States apart from some of its closest allies. 
Americans profess unquestioning belief in God and are far more willing to mix faith and politics than people in other countries, AP-Ipsos polling found..... Only Mexicans come close to Americans in embracing faith, the poll found. But unlike Americans, Mexicans strongly object to clergy lobbying lawmakers, in line with the nation's historical opposition to church influence (USA TODAY 6/6/2005. "Poll: Religious devotion high in U.S.", p.1)

3. Data cited on religious beliefs can be found at The Harris Poll \#11, "The Religious and Other Beliefs of Americans 2003" February 26, 2003 http://www.
harrisinteractive.com/harris_poll/index.asp?PID=359.

4. Among shooting rampages foremost in recent American history is the March, 2005 Red Lake Reservation high school shootings in Minnesota, where ten people died, including the gunman; the March, 1998 Jonesboro, Arkansas massacre where five students were killed; the Columbine killings in April, 1999, where fourteen students were killed followed by the suicides of the shooters; and the 1997 West Paducah, KY school shooting where a fourteen year old gunman killed three classmates.

\section{References}

Brown, R.H. 1983. "Dialectical Irony: Literary Form and Sociological Theory." Poetics Today 4:543-564 .

Center for Disease Control. Retrieved May, 2007. School associated violent deaths. Retrieved May 20, 2007 (http://www.cdc. gov/ncipc/sch-shooting.htm).

Chesterton, G.K. 1909. George Bernard Shaw. Rockville, MD: Wildside Press.

Cukier, Wendy and Victor W. Sidel. 2006. The Global Gun Epidemic. Westport, CT: Greenwood Press.

Debord, G. [1967] 1995. The Society of the Spectacle. Translated by. D. Nicholson-Smith. New York: Zone Books.

Durkheim. Emile. [1912] 1995. The Elementary Forms of Religious Life. Translated by K. Fields. New York: The Free Press.

Einstein, A. 1950. On the Generalized Theory of Gravitation. Scientific American 182:13-17.

Freud, S. 1900. Interpretation of Dreams. London: Hogarth Press.

Garfinkel, H. 1967. Studies in Ethnomethodology. New Jersey: Prentice Hall.

Harris, Louis. 2007. The Hollis Poll \#11, "The Religious and Other Beliefs of Americans 2003.” Retrieved April 17 (http:// www/harrisinteractive.com).

Herda-Rapp, A. 2003. "The Social Construction of Local School Violence Threats by the News Media and Professional Organizations." Sociological Inquiry 73(4):545-575.

Kimmel, M. 2005. Masculinity and Gun Violence: The Personal Meets the Political. United Nations. Retrieved April 1, 2007 (http://www.womenwarpeace.org/issues/smallarms/docs/ kimmelspeech).

Marcuse, H. 1969. An Essay on Liberation. Boston: Beacon Press.

Mason, H. 2005. "Public: Society Powerless to Stop School Shootings." The Gallup Poll Tuesday Briefing. 57-59.

Mehta, Deepak. 2006. "Collective Violence, Public Spaces, and the Unmaking of Men." Men and Masculinities 9(2):204-225.

Merriam-Webster Dictionary (http:www.m-w.com/dictionary/ yahoo).

Miner, H. 1956. "Body Ritual among the Nacirema. American Anthropologist 58:503-507.

National Shooting Sports Foundation [45]. Retrieved April 25 (http:www.nsff.org/news/PR_idx.cfm?PRloc=common/ $\mathrm{PR} / \& \mathrm{PR}=060506 . \mathrm{cfm})$.
Newman, K. 2004. Rampage: The Social Roots of School Shootings. New York, NY: Basic Books.

Newspaper Association of America. 2004. Retrieved April 16 (www.naa.org/info/facts04/interactive.html).

New York Times. . Retrieved May 11, 2007 (http// www.nytimes.com/imagepages/2007/04/21/ weekinreview/20070422_196_MARSHGRAPHIC./html).

Nietzsche, Friedrich. 1960. Joyful Wisdom. New York: Frederick Ungar.

Nugent, T. 2007. "Gun-free Zones are Recipe for Disaster." Retrieved April 20, 2007 (http://www.cnn.com).

Ogburn, W.F. 1964. On Culture and Social Change, edited by O.D. Duncan. Chicago and London: The University of Chicago Press.

President of University of Pennsylvania. Retrieved April 18 (http:www.Upenn.edu).

Swift, J. 1704. A Tale of a Tub. New York: Signet.

Swift, J. [1726] 1999. Gulliver's Travels. New York: Signet.

Thatcher, Margaret.1987. "Interview." Womens's Own, October 31, 1987:4.

Thierer, Adam. 2007. "The Media Cornucopia. City Journal Spring (http://www.city-journal.org/html/17_2_media html).

Thoreau, H.D. 1906. Journal of Henry David Thoreau. Cambridge: Riverside Press.

Three Dead In Idaho Church Shooting. Retrieved April 16 Time (http://www.time.com).

Tocqueville, Alexis de. [1835] 2001. Democracy in America. New York: Signet Classics.

USA TODAY. 6/6/2005. "Poll: Religious Devotion High in U.S., p.1.

White house conference center briefing. 2007. Retrieved April 30, 2007 (http://www.whitehouse.gov/news/ releases/2007/04/20070416-1.html).

Wrong, D. 1961. “The Oversocialized Concept of Man in Modern Sociology." American Sociological Review 26:183-93. 
